Acta vet. scand. $1978,19,102-109$.

From the Department of Pharmacology and Toxicology, Veterinary College of Norway, Oslo.

\title{
ABSORPTION FROM WATER AS AN ALTERNATIVE METHOD FOR THE ADMINISTRATION OF SULPHONAMIDES TO RAINBOW TROUT, SALMO GAIRDNERI*
}

THE SIGNIFICANCE OF THE pKa VALUE OF THE SULPHONAMIDES AND THE $\mathrm{pH}$ AND SALT CONTENT OF THE WATER

By

Torill Bergsjф and Trond Helle Bergsjф

\begin{abstract}
BERGSJ $\emptyset$, T. \& T. H. BERGSJ $\emptyset$ : Absorption from water as an alternative method for the administration of sulphonamides to rainbow trout, Salmo gairdneri. The significance of the $p K a$ value of the sulphonamides and the $\mathrm{pH}$ and salt content of the water. Acta vet. scand. 1978, 19, 102-109. - The effect of variations in $\mathrm{pH}$ and salt concentration on the absorption by rainbow trout of sulphonamides from water was investigated. Two trials were carried out: 1) Absorption from fresh water of sulphanilamide ( $\mathrm{pKa}$ 10.4) and sulphadimidine ( $\mathrm{pKa} 7.4)$ at $\mathrm{pH} 4,6,8$ and 10 over a period of 96 hrs., and 2) Absorption from fresh water and sea water (salinity approx. 31\%o) of the same two sulphonamides at $\mathrm{pH} 6$ and 8 over a period of $24 \mathrm{hrs}$. The degree of acetylation of the two sulphonamides in rainbow trout was investigated.
\end{abstract}

sulphanilamide; sulphadimidine; rainbow trout, Salmogairdneri; absorption; pH; salt water; fresh w a ter; acetylation.

In drug therapy in fish there are problems which do not exist in connection with the treatment of mammals. The special anatomy and physiology of fish, as well as the large numbers usually to be treated, make individual administration of drugs

* The investigations were carried out with partial financial support from the Norwegian Fishery Research Council. 
impossible in most cases. Addition of the drug to feed is the method usually employed. However, feed uptake by fish may be minimal, e.g. at certain stages of development, at low water temperatures, or if the fish is weakened by disease.

In such circumstances, immersing the fish in medicated water with subsequent absorption of the medicament from the water may be an alternative. With this method of administration, the various water parameters such as temperature, $\mathrm{pH}$, salt content etc. may partly determine the degree of absorption. It should therefore be possible to increase absorption by manipulating one or more of the above-mentioned parameters.

When a medicament is added to water, there are several possible absorption routes. Absorption through intact skin is of relatively little significance (Parry 1966). In salt water a certain amount of absorption will take place from the intestine as a result of the fish drinking the surrounding medium (Motais \& Garcia-Romeu 1972). However, it is reckoned that absorption occurs mainly via the gills.

The amount of a drug which can pass across a biological membrane such as the gills and be transferred from an external (the surrounding water) to an internal (tissue fluids) aqueous phase will inter alia be dependent on the pKa value of the substance and the $\mathrm{pH}$ value of the water, as only non-ionized molecules are sufficiently fat soluble to be able to pass through a cell membrane. The significance of the $\mathrm{pH}$ of the water for absorption in fish has been demonstrated for a large number of drug (Sills \& Allen 1971, Hunn \& Allen 1974). Change of $\mathrm{pH}$ in the medium has previously been shown to influence the absorption of sulphadimidine by cod (Bergsj $\phi$ 1974).

The purpose of this work was to investigate the absorption from water of sulphadimidine (pKa 7.4) and sulphanilamide (pKa 10.4) in rainbow trout, Salmo gairdneri, in the $\mathrm{pH}$ range 4-10. Moreover, a preliminary comparison of sulphonamide uptake from fresh and salt water was also carried out.

When comparing absorption, it is the total amount of absorbed sulphonamide which is of interest. In the organism, sulphonamides will be partly inactivated by acetylation. As little data were available on this aspect in fish, it was natural to examine the degree of acetylation of the two sulphonamides. 


\section{MATERIAL AND METHODS}

Healthy rainbow trout (Salmo gairdneri) bred at the Fish Research Station, Sunndals $\phi$ ra, were used in the investigation. Average weight was $37 \mathrm{~g}$, age approx. 12 months. The investigation took place in May.

Natural $\mathrm{pH}$ in fresh water and salt water was 6.6 and 8.0, respectively, salt content $31 \%$, temperature in fresh water and salt water approx. $11^{\circ} \mathrm{C}$. The fish were kept in 120-l plastic tanks during the experiments and air was supplied via a compressor.

The amounts of sulphanilamide and sulphadimidine were calculated according to their molecular weight, $650 \mathrm{mg} / 1$ sulphadimidine (mol. 278) and $400 \mathrm{mg} / \mathrm{l}$ sulphanilamide (mol. 172).

The absorption experiment in fresh water with varying $\mathrm{pH}$ lasted 96 hrs., fish being taken out after 6, 12, 24, 48 and $96 \mathrm{hrs}$. $\mathrm{pH}$ in the tanks was adjusted to $4,6,8$ and 10 using $\mathrm{HCl}$ or $\mathrm{NaOH}$. An experiment lasting $24 \mathrm{hrs}$. with fish being taken out of each tank after 4, 12 and $24 \mathrm{hrs}$. was carried out in order to compare absorption from fresh and salt water, $\mathrm{pH} 6$ and 8 .

The fish were allowed to adapt to the salt water for $24 \mathrm{hrs}$. before addition of sulphonamide and regulation of $\mathrm{pH}$. Before sampling, the fish were rinsed in clean fresh water in order to avoid contamination of samples by water containing sulphonamide. The fish were killed by decapitation, the heart exposed, and blood samples taken using heparinized glass syringes. Blood from batches of three and three fish was pooled.

Free and total sulphonamide were determined according to the King et al. (1942) modification of the method of Bratton \& Marshall (1939). When determining the sulphonamide content in tissue, $5 \mathrm{~g}$ of fish was homogenized with $10 \mathrm{ml}$ distilled water and centrifuged. Analysis was carried out on the centrifugate.

\section{RESULTS}

The total concentration in blood of the two sulphonamides is shown in Fig. 1. The concentration of sulphanilamide showed little variation with changes in $\mathrm{pH}$. All measurements showed that the uptake of sulphadimidine was significantly higher at pH 6 than at pH 10, except after 6 hrs. (Wilcoxon's test, $\mathrm{P}<$ 0.05 ). There was no significant difference in uptake at $\mathrm{pH} 6$ and 8. 


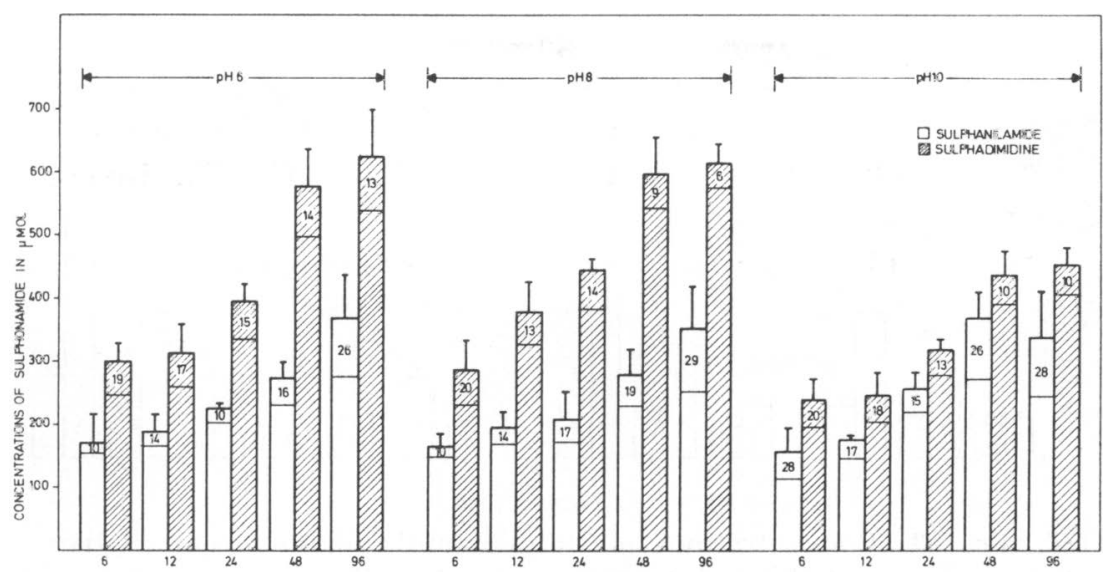

HOURS OF EXPOSURE

F ig u r e 1. Concentrations of sulphonamide in blood after exposure of the fish to $650 \mathrm{mg} / \mathrm{l}$ sulphadimidine and $400 \mathrm{mg} / 1$ sulphanilamide at different $\mathrm{pH}$ values for 6-96 hrs. The numbers on top of the columns indicate acetylation percentage.

The same absorption patterns, but with less marked differences, were found in connection with the tissue measurements (Fig. 2).

At $\mathrm{pH} \mathrm{4,} \mathrm{the} \mathrm{concentration} \mathrm{of} \mathrm{sulphanilamide} \mathrm{and} \mathrm{sulpha-}$ dimidine in blood after $6 \mathrm{hrs}$. was $502 \pm 141 \mu \mathrm{mol}$ and $565 \pm 18$ $\mu$ mol, respectively. The fish died between 6 and $12 \mathrm{hrs}$. after treatment was initiated. Control fish at $\mathrm{pH} 4$ died between 12 and 20 hrs. after transfer to $\mathrm{pH} 4$.

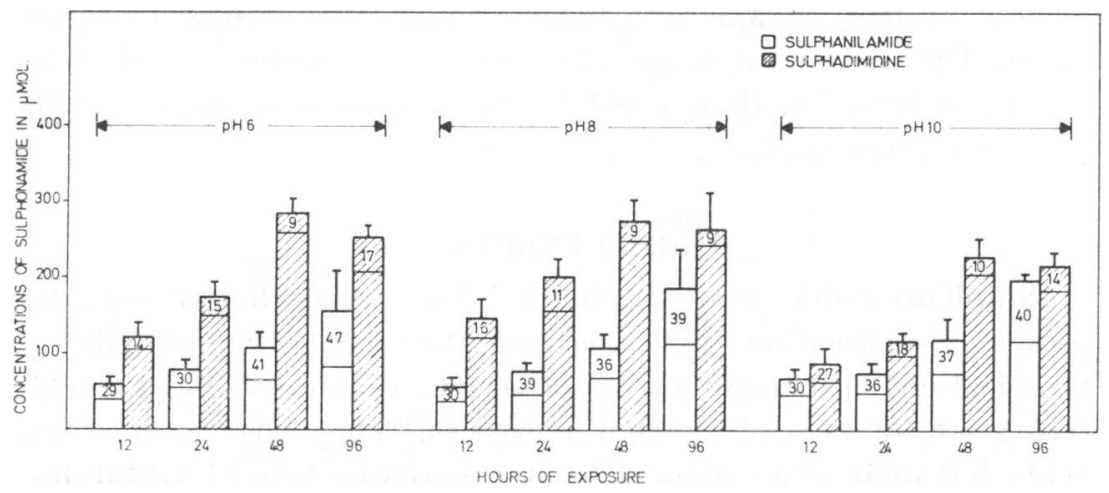

F i g u r e 2. Concentrations of sulphonamide in homogenized tissue after exposure of the fish to $650 \mathrm{mg} / 1$ sulphadimidine and $400 \mathrm{mg} / \mathrm{l}$ sulphanilamide at different $\mathrm{pH}$ values for 6-96 hrs. The numbers on top of the columns indicate acetylation percentage. 


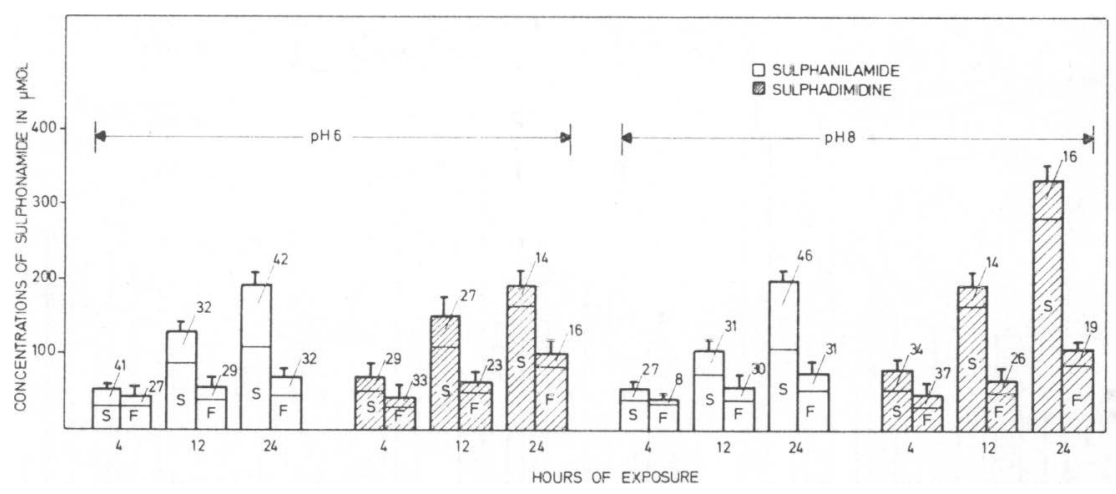

Fig u r e 3. Concentrations of sulphonamide in homogenized tissue after exposure of the fish to $650 \mathrm{mg} / 1$ sulphadimidine and $400 \mathrm{mg} / \mathrm{l}$ sulphanilamide in salt (S) and fresh (F) water at $\mathrm{pH} 6$ and 8 for $4-24 \mathrm{hrs}$. The numbers on top of the columns indicate acetylation percentage.

The acetylation process seems to differ for the two investigated sulphonamides. The degree of acetylation is shown in Figs. 1, 2 and 3. As regards sulphanilamide, the degree of acetylation increases with time, the lowest measurement being found after 4 hrs. ( $8 \%$ ), and the highest after 96 hrs. (47\%), whereas for sulphadimidine it decreases with time, the highest measurement being after 4 hrs. $(37 \%)$ and the lowest after 96 hrs. (9\%).

The total tissue concentration of sulphonamide after uptake from fresh and salt water is shown in Fig. 3. In the case of both sulphonamides, uptake is greater in salt water than in fresh water. Uptake of sulphadimidine from salt water at $\mathrm{pH} 8$ is significantly higher than at $\mathrm{pH} 6$, which is not in agreement with the other investigations.

\section{DISCUSSION}

Sulphanilamide and sulphadimidine were chosen for the present investigation, both because they could be suitable in practical chemotherapy and also because of their somewhat differing physico-chemical characteristics. They are both weak acids, but their pKa values differ quite greatly, being 7.4 (sulphadimidine) and 10.4 (sulphanilamide) respectively. They will react differently to changes in the $\mathrm{pH}$ of the water. According to Shore et al. (1957), the following formula can be used to 
calculate distribution on the two sides of a biological membrane (gills) with unequal $\mathrm{pH}$ on the two sides:

$$
\frac{\mathrm{C}_{1}}{\mathrm{C}_{2}}=\frac{1+10^{\mathrm{pH}_{1}-\mathrm{pKa}}}{1+10^{\mathrm{pH}_{2}-\mathrm{pKa}}}
$$

where $\mathrm{C}_{1}$ and $\mathrm{C}_{2}$ are the total concentrations of the drug on the two sides of the membrane. If blood $\mathrm{pH}$ is put at 7.4 , these concentrations can be calculated. The following calculated values are thus obtained for $\mathrm{c}$ (fish)/c(water):

$\begin{array}{ccc} & \text { Sulphanilamide } & \text { Sulphadimidine } \\ \text { pH } 4 & 1.00099 & 1.99 \\ \text { " } & 1.00096 & 1.92 \\ \text { " } 8 & 0.998 & 0.40 \\ \text { "10 } & 0.715 & 0.005\end{array}$

Sulphanilamide will, on account of its high pKa value, show relatively small changes in the degree of ionization in the $\mathrm{pH}$ range 6-10, and consequently little change in absorption. Sulphadimidine, with pKa 7.4, will show considerable change in degree of ionization when the $\mathrm{pH}$ of the water passes 7.4.

The high sulpha uptake at $\mathrm{pH} 4$ cannot be explained solely on the basis of the degree of ionization. Ionization is more or less the same for both sulphonamides at $\mathrm{pH} 4$ and $\mathrm{pH}$ 6. In addition, there is the circumstance that blood $\mathrm{pH}$ will fall with very low $\mathrm{pH}$ in the surrounding medium (Packer \& Dunson 1970). Fall in blood pH should, according to the equation above, lead to reduced absorption. In the light of present knowledge it is impossible to state whether the high sulphonamide concentration at $\mathrm{pH} 4$ is the result of changes in the gills, uptake via other organs such as skin or gut, or reduced excretion. However, it is known that at low $\mathrm{pH}$ values, fundamental physiological changes will occur, inter alia in the ionic balance of the fish (Evans 1975).

For both sulphonamides, uptake from salt water was higher than uptake from fresh water. This effect can be partly explained by supplementary absorption from the gut. The question as to whether this situation can explain all the difference in absorption in our case cannot be settled until complete light is thrown on the kinetics, inter alia be means of excretion experiments.

The fact that absorption from salt water was higher at $\mathrm{pH} 8$ than at $\mathrm{pH} 6$ may indicate that an adaptation period of $24 \mathrm{hrs}$. 
was not sufficient. Adaptation of salmon fry to salt water has been shown to take several days (Potts et al. 1970).

\section{CONCLUSION}

The purpose of the investigation was to see if variation of water parameters could influence absorption of sulphonamides from water. It has to be said that, as regards rainbow trout, the increased absorption which can be obtained by changing $\mathrm{pH}$ within the range in which fish can survive is moderate.

The results indicate that the absorption of sulphonamides can be influenced to a considerable degree by changing the salt concentration. This may possibly be of practical significance.

\section{ACKNOWLEDGEMENTS}

The experiments were carried out at the Fishery Research Station, Sunndals $\emptyset \mathrm{ra}$. We thank the staff there for assistance during the investigation. We are especially grateful to laboratory technician Thorbjørn Myrvold, of the Department of Pharmacology and Toxicology, Veterinary College of Norway. Mr. Myrvold participated in the practical work involved and carried out all the analyses.

\section{REFERENCES}

Bergsjø, T.: The absorption of sulphadimidine in cod fish. Acta vet. scand. $1974,15,442-444$.

Bratton, A. C. \& E. K. Marshall: New coupling component for sulfanilamide determination. J. biol. Chem. 1939, 128, 537-550.

Evans, D. H.: Ionic exchange mechanisms in fish gills. Comp. Biochem. Physiol. 1975, 51A, 491-495.

Hunn, J. B. \& J. L. Allen: Movement of drugs across the gills of fishes. Ann. Rev. Pharmacol. 1974, 14, 47-55.

King, E. H., G. A. D. Haslewood, G. E. Delory \& D. Beall: Microchemical methods of blood analysis. Lancet 1942, 242, 207-209.

Motais, R. \& F. Garcia-Romeu: Transport mechanisms in the teleostean gill and amphibian skin. Ann. Rev. Physiol. 1972, 34, 141-176.

Packer, R. K. \& W. A. Dunson: Effects of low environmental $\mathrm{pH}$ on blood $\mathrm{pH}$ and sodium balance of brook trout. J. exp. Zool. 1970, $174,65-72$.

Parry, G.: Osmotic adaptation in fishes. Biol. Rev. 1966, 41, 392-441.

Potts, W. T. W., M. A. Foster \& J. W. Stather: Salt and water balance in salmon smolts. J. exp. Biol. 1970, 52, 553-564.

Shore, P. A., B. B. Brodie \& C. A. M. Hogben: The gastric secretion of drugs: A pH partition hypothesis. J. Pharmacol. exp. Ther. 1957, 119, 361-369.

Sills, J. B. \& J. L. Allen: The influence of $\mathrm{pH}$ on the efficacy and residues of Quinaldine. Trans. Amer. Fish. Soc. 1971, 100, 544-545. 


\section{SAMMENDRAG}

Absorpsjon fra vannet som alternativ administrasjonsmåte for sulfonamider til regnbueфrret, Salmo gairdneri. Betydningen av sulfonamidenes $\mathrm{pKa}$-verdi og vannets $\mathrm{pH}$ og saltinnhold.

Effekten av varierende $\mathrm{pH}$ og saltkonsentrasjon på regnbueørretens absorpsjon av sulfonamider fra vann ble unders $\phi k t$. Det ble foretatt to fors $\varnothing \mathrm{k}$ : 1) Absorpsjon fra ferskvann av sulfanilamid (pKa 10,4) og sulfadimidin ( $\mathrm{pKa} 7,4)$ ved $\mathrm{pH} \mathrm{4,6,8}$ og 10 over 96 timer, og 2) Absorpsjon fra ferskvann og sjøvann (salinitet ca $31 \%$ ) av de samme to sulfonamider ved pH 6 og 8 over 24 timer. Acetyleringsgraden av de to sulfonamidene hos regnbue $\varnothing$ rret ble unders $\varnothing$ kt.

(Received September 8, 1977).

Reprints may be requested from: Torill Bergsjø, The Department of Pharmacology and Toxicology, Veterinary College of Norway, P.O.Box 8146, Oslo Dep., Oslo 1, Norway. 